\title{
THE GERMAN REFORMATION
}

\section{R. W. Scribner, University of Cambridge}

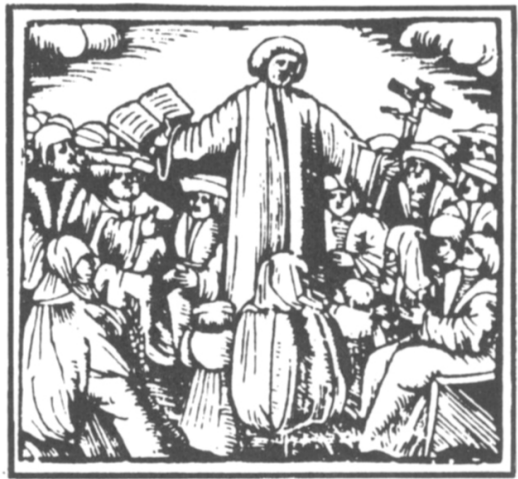

Dr. Scribner sums up some of the new approaches to the history of the Reformation of the Church, with special emphasis on the German Reformation, and presents a new interpretation of the period. An excellent survey for student use.

1986, $96 \mathrm{pp}$

ISBN 0-391-03362-X, paper \$7.95

Please order from your bookstore or call Humanities Press at 1-800-221-3845. Visa and Mastercharge welcome

International reproduces this
publication in microform:
microfiche and 16mm or
about this publication or any
of the more than 13,000 titles




\title{
Centuries of History Come to Life...
}

\section{DOMESDAY BOOK}

\section{Through Nine Centuries}

By ELIZABETH M. HALLAM. Since 1086, when William the Conqueror ordered this great survey of landholding in England, Domesday Book has endured as a document of undying interest. To Anglo-Saxons it was a symbol of Norman oppression; for 14th-century peasants it held out the hope of escape from the burdensome services demanded by their landlords. By the mid-Victorian era it had become a cult object; its eighth centenary stimulated a flowering of historical scholarship; the ninth witnesses the analysis of its text by computer.

Published to coincide with the 900th anniversary of the making of Domesday Book, this absorbing account provides in fascinating detail the story of one of the world's greatest written treasures. With 79 illustrations and 14 maps. Selected by History Book Club. $\$ 24.95$

\section{THE CUSTOMS AND CEREMONIES OF BRITAIN}

\section{An Encyclopaedia of Living Traditions}

By CHARLES KIGHTLY. Throughout the British Isles, hundreds of fascinating customs and ceremonies-many of them centuries oldcontinue to be observed. Charles Kightly unfolds a broad and colorful tapestry of those that survive to this day-folklore and calendar customs; royal ceremonies; remnants of life in the Middle Ages and of vanished farming ways; commemorations of loved, hated or merely eccentric people;-celebrations of deliverance from plagues and perils past.

Arranged alphabetically by custom, this book details the dates, times, and locations of the ceremonies; an extensive regional index of place names also gives a guide to the events in a particular area. Here is a compelling text for everyone interested in British history, culture, and tradition, as well as a unique guide for visitors in search of colorful and unusual events. With over 200 illustrations, 12 in color. $\$ 24.95$

\section{Thames and Hudson Inc.}

\author{
500 Fifth Avenue, New York $10110 \bullet$ Distributed by W.W. Norton \& Co.
}




\title{
The Best of GENTLEMAN'S MAGAZINE 1731-1754
}

\author{
edited by Earl Reitan
}

An anthology of articles on politics, religion, science, exploration, marriage and family life, theatre and the arts, medicine, and popular culture from the most influential periodical of the eighteenth century.

\section{STUDIES IN BRITISH HISTORY}
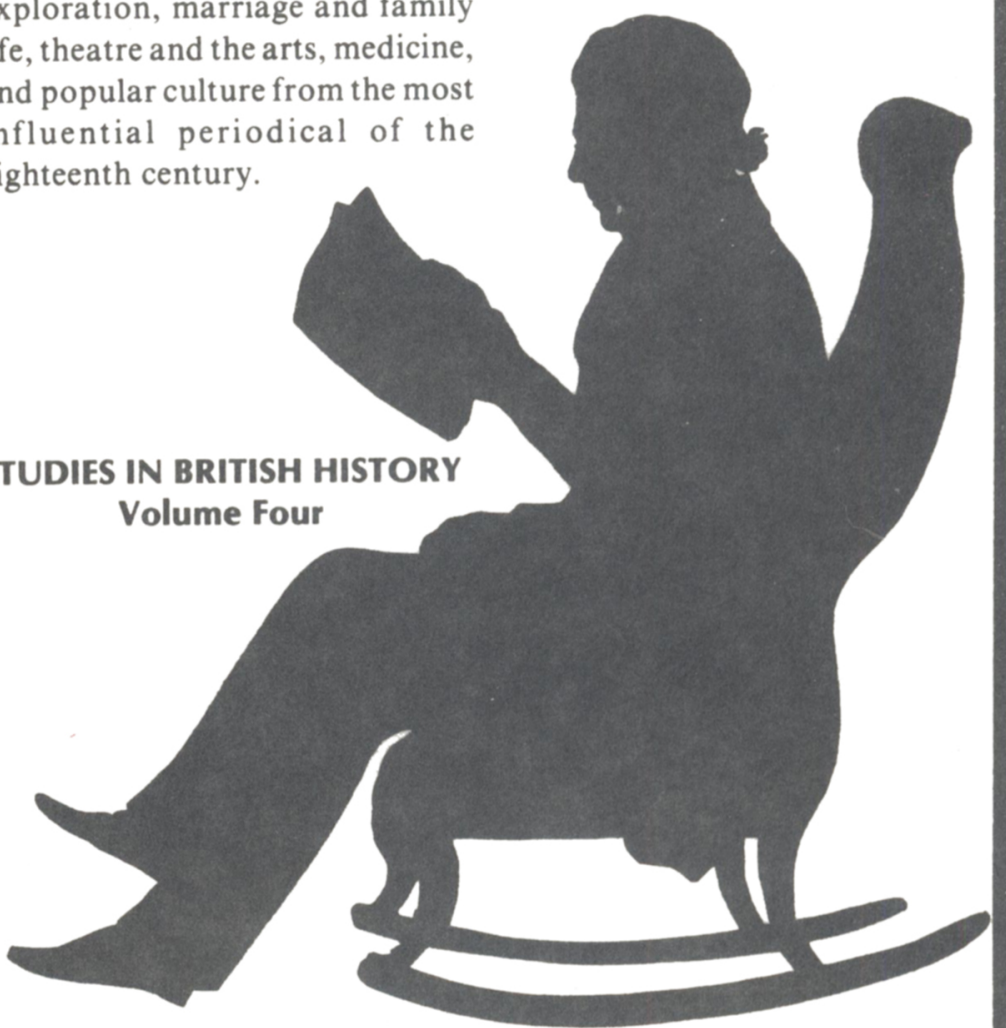

The Edwin Mellen Press invites proposals for monographs, bibliographies, and other specialized research for inclusion in this series.

THE EDWIN MELLEN PRESS 421 Center Street * Lewiston, N.Y. 14092 